\title{
Phytochemical Screening and Assessment of Antibacterial, Antioxidant and Antihelminthic Activities of Sarcocephalus latifolius Leaves
}

\author{
Jeff B. Iteku, Ornella V. Makaya, Clément L. Inkoto, Samy Ngunde-te-Ngunde, \\ Emmanuel M. Lengbiye, Joseph D. Tshidibi, and Koto-Te-Nyiwa Ngbolua
}

\section{ABSTRACT}

\begin{abstract}
The main objective of our study was to determine the cheminical composition and to assess the antioxidant, antibacterial and antihelminthic activities of the leaves extracts of $S$. latifolius. The antibacterial activity of $S$. latifolius leaves extracts was assessed using micro-dilution method. In end, the antioxidant capacity of different plant extracts has been evaluated by determining their ability to reduce iron (III) to iron (II) and DPPH radical. The results obtained revealed that the dry matter of the powder of the $S$. latifolius leaves is rich in fibers, crude proteins, lipids and carbohydrates. Its water content was moderate $(14.3 \%)$; the leaves of $S$. latifolius are rich in mineral elements like calcium $(\mathrm{Ca})$, magnesium $(\mathrm{Mg})$, potassium $(\mathrm{K})$ and iron (Fe); the plant has the main groups of secondary metabolites such as total polyphenols, flavonoids, tannins, alkaloids, bound and free quinones, steroids and tri-terpenes, while it is poor in anthocyanins, leucoanthocyans and saponins. The bacterial strains used were less sensitive to $S$. latifolius leaf extracts (MIC greater than or equal to $500 \mu \mathrm{g} / \mathrm{mL}$ ). The extracts of this plant showed significant antioxidant and antihelmintic activity, with a strong correlation between the methods used to evaluate the antioxidant potential of DPPH and FRAP. Due to their interesting functional properties, this plant could be used in the formulation of a nutraceutical with strong antioxidant power to improve the antioxidant status of consumers, but also in the management of helminthiases.
\end{abstract}

Keywords: Bioactivity, Evidence-based Medicine, Medicinal plant, Sarcocephalus latifolius, Traditional medicine.

\section{INTRODUCTION}

In time, the plants have always been used as medicines. Herbal medicines are considered to be less toxic and milder than pharmaceutical drugs. It is estimated that about $28 \%$ of the medicines used in the world are actually of plant origin [1]. The claimed natural origin of these medicines gives them the reputation of being safer and better than so-called
Submitted : Novermber 01, 2020

Published : August 31, 2021

ISSN: $2684-1827$

DOI: $10.24018 /$ ejfood.2021.3.4.158

\section{J. B. Iteku}

Department of Biology, Faculty of Sciences, University of Kinshasa, Democratic Republic of the Congo.

(e-mail: jjiteku@yahoo.fr)

O. V. Makaya

Department of Biology, Faculty of Sciences, University of Kinshasa, Democratic Republic of the Congo.

(e-mail: orny6mak@gmail.com)

C. L. Inkoto*

Department of Biology, Faculty of Sciences, University of Kinshasa, Democratic Republic of the Congo.

(e-mail: clementinkoto@gmail.com)

S. Ngunde-te-Ngunde

Higher Pedagogical Institute of Yakoma,

Nord-Ubangi City, Democratic Republic of the Congo.

(e-mail: samyngunde@gmal.com)

E. M. Lengbiye

Department of Biology, Faculty of Sciences, University of Kinshasa, Democratic Republic of the Congo.

(e-mail: emmanuellengbiye@ gmail.com) J. D. Tshidibi

Department of Biology, Faculty of Sciences, University of Kinshasa, Democratic Republic of the Congo.

(e-mail: tshidibijoseph11@ gmail.com)

K. N. Ngbolua

Department of Biology, Faculty of Sciences, University of Kinshasa, Democratic Republic of the Congo.

(e-mail: jpngbolua ${ }^{@}$ unikin.ac.cd)

*Corresponding Author chemical medicines. Africa has important plant biodiversity [2]. Its flora is particularly rich in medicinal plants that local populations know and use. It has been reported that there are about 300,000 medicinal species and that only $10 \%$ have been studied from a chemical and pharmacological point of view [3]. Indeed, the World Health Organization (WHO) estimates that more than $80 \%$ of the African population continues to rely on medicinal species to provide primary health care [4], [5]. The Democratic Republic of Congo is a reservoir of 
biodiversity, both flora, and fauna [6], [7]. Its flora abounds in medicinal plants of biopharmaceutical interest and is capable of providing new bioactive molecules [8]. Thus, the study of plant chemistry is still of brilliant topicality in spite of its antiquity. Among the compounds of plant, origin are coumarins, alkaloids, phenolic acids, tannins, terpenes, flavonoids, etc. [9]. [5] which are endowed with interesting pharmacological properties including antioxidant, antibacterial, and antihelmintic activity. To this end, the search for natural substances with antibacterial, antioxidant and antihelmintic activity is an important scientific challenge in the treatment of several common diseases. In order to scientifically value the phytotherapeutic richness of the DRC, our choice was made on $S$. latifolius used in traditional Congolese medicine in the hypothesis that it would contain secondary metabolites likely to confer antihelmintic, antibacterial and antioxidant properties. The objective of this study was to chemically and bio-actively analyze the leaves of $S$. latifolius.

\section{MATERIAL AND METHODS}

\section{A. Material}

Plant: The leaves of $S$. latifolius were used in this study. These leaves were harvested in the Northern ProvinceUbangi more precisely in the territory and sector of Yakoma. The Systematic analysis of this plant was carried out at the Laboratory of Systematic Botany and Plant Ecology, Department of Biology, Faculty of Sciences, University of Kinshasa. These samples were dried out in room temperature $\left( \pm 27{ }^{\circ} \mathrm{C}\right)$ at the Molecular Bio-Prospection Laboratory, Department of Biology for two weeks and then ground to obtain fine powder for further analyses.

Worm specimens: In this study, two worm specimens (Behamia rosea Michaelsen and Behamia itoliensis) were collected from the ponds of Monastère Prieure Notre Dame de l'Assomption and identified at the Natural Resources Management Laboratory, Faculty of Agricultural Sciences, University of Kinshasa.

Bacterial Strains: In the present study, two bacterial strains were used namely Escherichia coli ATCC 8739 and Staphylococcus aureus ATCC 25923. These strains were provided by the Laboratory of Microbiology, Faculty of Pharmaceutical Sciences, University of Kinshasa.

\section{B. Methods}

\section{1) Evaluation of the chemical composition}

\section{1) Determination of humidity}

Dry matter was determined by AOAC Method 925.10 (1990). Briefly an empty cup was cleaned, dried, and weighed (PO). To this dish $2 \mathrm{~g}$ of sample was added and the whole (P1) was placed in an oven at $105^{\circ} \mathrm{C}$ for 24 hours. After this drying time, the dish was taken out of the oven and cooled in a desiccator (P2O5) before being weighed again (P2).

\section{2) Determination of total ash}

Crude ash content was determined by AOAC Method 920.87 [9]. It consists of mineralizing $2 \mathrm{~g}$ of the powder contained in the porcelain crucible in a pasteurizing furnace. The vacuum mineralization crucible was cleaned, dried and weighed (PO). The crucible containing the powder was weighed again $\left(\mathrm{P}_{1}\right)$ and then placed in the oven at $105^{\circ} \mathrm{C}$ for 4 hours. After drying, the crucible was removed from the oven, cooled in a desiccator $\left(\mathrm{P}_{2} \mathrm{O}_{5}\right)$ and weighed again $\left(\mathrm{P}_{2}\right)$. Once weighed, the crucible was placed in the oven at $500{ }^{\circ} \mathrm{C}$ for about 6 hours, cooled in the desiccator and weighed again. The ash content was the mass of product remaining in the crucible after mineralization in relation to the total dry mass of the product. The result expressed represents the average of three trials.

\section{3) Determination of crude proteins}

The crude protein content was determined by the Kjeldahl method. $1 \mathrm{~g}$ of the powder was weighed into the Kjeldahl tube and $3 \mathrm{~g}$ of mixed catalyst was added, followed by $20 \mathrm{ml}$ of concentrated $\mathrm{H}_{2} \mathrm{SO}_{4}$. Afterwards, the sample was mineralized until a clear solution was obtained. Then the entire solution was placed in a 100 mal volumetric flask and cooled in the open air. A few minutes later, the solution was returned to the volumetric flask and homogenized. Then $50 \mathrm{ml}$ of $33 \%$ $\mathrm{NaOH}$ was added to the solution, placed in the nitrogen distiller, and collected $40.5 \mathrm{ml}$ of the distillate in an Erlen Meyer containing $10 \mathrm{ml}$ of $0.1 \mathrm{~N} \mathrm{H}_{2} \mathrm{SO}_{4}+$ a few drops of mixed indicators. Finally, we titrated with a $0.1 \mathrm{~N}$ solution up to the equivalence point. Crude protein content was converted to nitrogen using Crisand and Sands (1978).

\section{4) Determination of total lipids}

The fat content was determined by the Sohxelt method. 2 $\mathrm{g}$ was weighed for 3 trials and $20 \mathrm{~mL}$ of concentrated $\mathrm{HCl}$ was added and then disintegrated on the hot plate to obtain a blackish leg. Afterwards, $100 \mathrm{~mL}$ of hot water was poured into the leg, then filtered until the blackish leg stuck on the spade was recovered and left to air dry. Then the filter paper was inserted into the cartridge. The empty glass capsule was weighed and $50 \mathrm{~mL}$ of petroleum ether was added and placed at the same time as the cartridge to the fat extractor. After this, the cartridge was heated for 40 minutes and rinsed for 15 minutes, then reweighed after cooling in the desiccator and the fat extractor was fixed.

\section{5) Determination of total fibre and carbohydrate content}

The total ash and carbohydrate content was determined by the method used by Makengo (2018). While the energy value was deducted by applying the following formula:

$$
\begin{gathered}
\text { Energy }(\text { in Kcal })=(\% \text { protein } \times 4)+(\% \text { fat } \times 9)+ \\
(\% \text { carbohydrates } \times 4)
\end{gathered}
$$

\section{6) Chemical screening}

The determination of secondary metabolites was performed according to the standard method used by Nkasa et al. [10].

\section{7) Determination of mineral elements}

The trace element content was determined according to the method used by Hanane et al. [11]. These mineral elements were measured in the residue of the calcined product at 500 $\mathrm{C}^{\circ}$ for 5 hours, with a test sample of $15 \mathrm{~g}$ for the leaves. The determination of the trace elements studied (Calcium, Potassium, Magnesium, Iron) was carried out by the aqua regia method used by Hanane et al. [11]. 2 to $3 \mathrm{~mL}$ of aqua regia were added to $0.15 \mathrm{~g}$ of the mineral matter, heated and left to evaporate dry. Then 25 to $30 \mathrm{~mL}$ hydrochloric acid (2M) was added until completely dissolved and the results 
were read using UV-visible spectrophotometry (LGS 53) at a wavelength of 525 nanometres.

\section{Evaluation of Biological Activities \\ 1) Evaluation of antibacterial activity}

The antibacterial activity was evaluated by the microdilution method described by Bongo et al. [12] in liquid medium. The extract to be tested $(20 \mathrm{mg}$ ) was previously dissolved in $250 \mu \mathrm{l}$ of DMSO (Dimethyl sulfoxide) and the final volume was adjusted to $5 \mathrm{ml}$ with Mueller Hinton culture medium (final DMSO concentration equal to $5 \%$ ). The bacterial suspension is prepared by placing in $2 \mathrm{ml}$ of physiological water for each strain, two colonies isolated from the strains to be tested (Staphylococcus aureus and Escherichia coli) by incubating for 24 hours in order to obtain $0.5 \mathrm{McFarland}(108$ cells $/ \mathrm{mL})$ at $37{ }^{\circ} \mathrm{C}$. The bacterial suspension is then diluted to 106 cells $/ \mathrm{mL}$ (1/100 dilution). The micro-dilution test is performed in 96-well round bottom sterile polystyrene microplates. Briefly, $100 \mu \mathrm{l}$ of culture medium is placed in the wells (2-9) and then in the $11^{\text {th }}$ and $12^{\text {th }}=$ control columns). Using a micropipette, $200 \mu \mathrm{l}$ of each extract to be tested $(1000 \mu \mathrm{g} / \mathrm{ml})$ is placed in wells 1 (the wells of the first column). $100 \mu$ of each extract stock solution is then taken for serial 2-in-2 dilutions up to the ninth column. The last 100 microliters (column 9) are discarded. 5 $\mu \mathrm{l}$ of inoculum $(108 \mathrm{CFU} / \mathrm{ml})$ is taken aseptically with a micropipette and added to all wells of the microplate except the wells of the 11th column for bacterial growth control (inoculum and culture medium). The wells of the 12th column will be used as a sterility control of the culture medium. The microplates are incubated in an oven at $37{ }^{\circ} \mathrm{C}$ for 24 hours. After this period, $3 \mu \mathrm{l}$ of Resazurin $1 \%$ dye (7Hydroxy-3H-phenoxazin-3-one 10-oxide) is added to each well and the microplates are then incubated for 4 hours. The minimum inhibitory concentration (first wells showing no bacterial growth) is determined after 24 hours.

\section{2) Evaluation of antihelmintic activity in vitro}

In vitro antihelmintic activity was evaluated according to the method used by Dash et al. [13] The extracts of the plants to be tested were previously dissolved in physiological water $(0.9 \%)(5 \mathrm{mg} / \mathrm{mL})$ in order to have a stock solution. The stock solution was diluted serially to optimize concentrations ranging from $10 \mathrm{mg} / \mathrm{ml}$ to $0.6125 \mathrm{mg} / \mathrm{ml}$. A standard solution (Albentel) which served as a positive control was prepared under the same conditions as the extract. Distilled water was used as the negative control. The worms, previously washed, were divided into three batches containing three specimens per petri dish. In the first batch: a series of boxes containing the extract and earthworms, with three worms per box for each concentration; in the second batch: the worms were dewormed (standard) using the same procedure as in the first batch and the last batch, with distilled water (negative control). The boxes were placed at room temperature for 48 hours while proceeding by observation. The rate of paralysis of each concentration for each given dose as a function of contact time was also evaluated. The mortality rate (TM) was also determined for each of the concentrations of the extracts according to the following formula:

$\mathrm{TM}(\%)=($ No. of dead worms/total no. of worms in petri dish) $\times 100$

\section{3) Evaluation of antioxidant activity}

\section{1) Total reducing power}

The antioxidant capacity of different plant extracts has been evaluated by determining their ability to reduce iron (III) to iron (II) [14]. Briefly, in a test tube, $1 \mathrm{~mL}$ of each extract is mixed with $2.5 \mathrm{ml}$ of a phosphate buffer solution $(0.2 \mathrm{M}$, $\mathrm{pH}$ 6.6) and $2.5 \mathrm{~mL}$ of $1 \%$ potassium hexacyanoferrate $\left[\mathrm{K}_{3} \mathrm{Fe}(\mathrm{CN})_{6}\right]$ solution. This is incubated for 30 minutes at $50^{\circ} \mathrm{C}$ in a water bath. Then $2.5 \mathrm{ml} 10 \%$ trichloroacetic acid is added and the mixture is centrifuged at $3000 \mathrm{rpm}$ for 10 minutes in a centrifuge. Then $2.5 \mathrm{ml}$ of the supernatant is taken and mixed with $2.5 \mathrm{ml}$ of distilled water and $0.5 \mathrm{ml}$ of a $0.1 \%$ aqueous solution of $\mathrm{FeCl}_{3}$. The absorbance is read at $700 \mathrm{~nm}$. The total reducing power is expressed as ascorbic acid equivalent (mg ascorbic acid/g powder).

\section{4) DPPH radical method}

\section{1) Sample Preparation}

Dissolve $10 \mathrm{mg}$ dry extract of each sample in $1 \mathrm{~mL}$ methanol for polar extracts. Make dilutions to have the following concentration levels: $8 \mathrm{mg} / \mathrm{ml}, 6 \mathrm{mg} / \mathrm{mL}, 4 \mathrm{mg} / \mathrm{mL}$ and $2 \mathrm{mg} / \mathrm{mL}$.

\section{2) DPPH-test}

\subsection{1) Principle}

This method is based on the degradation of the DPPH- (2,2 DiPhenyl-1-PicrylHydrazyl) radical. The DPPH- radical is a purple colored radical, the addition of antioxidant reduces this radical and causes discoloration of the mixture; this discoloration of the radical measured by spectrophotometer at $517 \mathrm{~nm}$ is proportional to the concentration of antioxidants [15].

\subsection{2) Preparation of the DPPH radical}

-Dissolve $3.2 \mathrm{mg}$ of DPPH in $100 \mathrm{~mL}$ of $80 \%$ methanol.

- Store the solution in a dark place for at least one hour.

- The absorbance of this solution should be adjusted to $0.7 \pm$ 0.05 with $80 \%$ methanol.

\subsection{3) Contacting the sample with the radical}

In a test tube, place $20 \mu 1$ of ethanol with $1980 \mu 1$ of the solution of the DPPH: control solution (3 repetitions). In a test tube, place $20 \mu \mathrm{L}$ of the sample solution for each concentration (at 3 repetitions), add to the $1980 \mu$ l solution of the DPPH- radical analysis solution. Allow to incubate in the dark for 30 minutes.

\subsection{4) Absorbance reading at $517 \mathrm{~nm}$}

Read successively the solutions for each concentration (3 repetitions) with the spectrophotometer at $517 \mathrm{~nm}$ : the blank (methanol), the control solution and the sample solutions.

\section{Determination of the radical inhibition power}

The percentage inhibition of the DPPH radical by the sample was determined using the following formula:

$$
\% \text { inhibition }=[1-(\mathrm{Ax} / \mathrm{Ac})] \times 100
$$

where Ax: the absorbance of the DPPH radical in the presence of the extract;

Ac: the absorbance of the DPPH radical (control solution). 


\section{RESULTS AND DISCUSSION}

\section{A. Extraction Yields}

Fig. 1 shows the extraction yield of S. latifolius leaf extract.

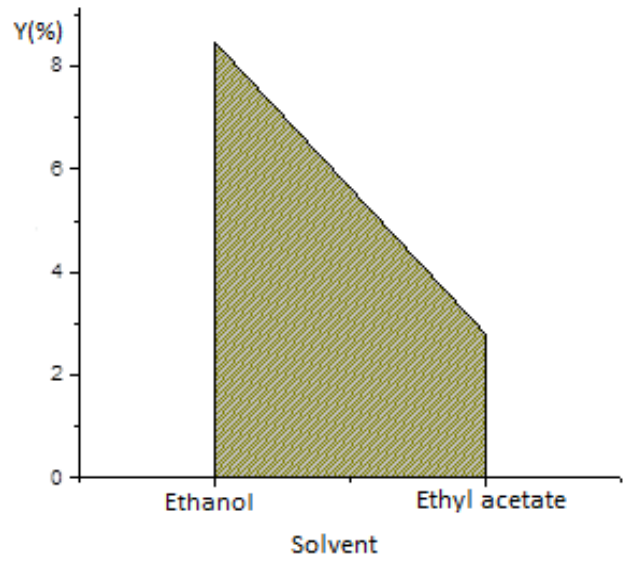

Fig. 1. Extraction yield of S. latifolius leaf extracts (Y: yield).

It can be seen from this figure that the yield obtained with ethanolic extract (more polar solvent) is higher than that of ethyl acetate (less polar solvent). This also shows that the quantitatively important metabolites in the leaves of $S$. latifolius are those which pass easily into the more polar solvents, notably polyphenols including anthocyanins, tannins, flavonoids, but also saponins, alkaloids, etc. [5].

\section{B. Phytochemical Composition}

Table I shows the results of the chemical composition per 100 grams of dry matter of S. latifolius leaves.

\begin{tabular}{cc} 
TABLE 1: CHEMICAL COMPOSITION OF S. LATIFOLIUS LEAF DRY MATTER \\
\hline Dosed & Concentration (in \% of dry weight) \\
macronutrients & - \\
Humidity & $24,3 \pm 2,1$ \\
Protein & $11,3 \pm 1,5$ \\
Ashes & $35,3 \pm 1,1$ \\
Fibers & $7,2 \pm 1,4$ \\
Carbohydrates & $22 \pm 3,6$ \\
Fat & 324 \\
Energy/kcal &
\end{tabular}

As can be seen in this table that $S$. latifolius leaves contain $35.3 \%$ fiber, crude protein is $24.3 \%$, lipids $22 \%$ and carbohydrates $7.2 \%$ respectively. These results are similar to Plassart research (2015) which shows that leaves and fruits contain a significant amount of the basic nutrients such as protein, carbohydrates, lipids and fiber. This high fiber content $(35.3 \%)$ would be a good source of fiber for a normal diet [16]. The results of the chemical composition of fresh $S$. latifolius leaf material are given in the table below (Table II).

TABLE II: CHEMICAL COMPOSITION OF FRESH S. LATIFOLIUS LEAF

\begin{tabular}{cc} 
& MATERIAL \\
\hline Dosed macronutrients & Concentration (\% of fresh weight) \\
\hline Humidity & 14,3 \\
Protein & 20,8 \\
Ashes & 9,7 \\
Fibers & 30,2 \\
Carbohydrates & 6,2 \\
Fat & 18,8 \\
Energy/kcal & 521,6 \\
\hline
\end{tabular}

From this table, it can be seen that $S$. latifolius leaves contain $30.2 \%$ fiber, $20.8 \%$ crude protein, $18.8 \%$ fat, $14.3 \%$ water, and $6.2 \%$ carbohydrates respectively. These results are in line with Plassart's research [16] which confirms that leaves and fruit contain an appreciable amount of basic nutrients such as protein, carbohydrates, lipids and fiber. Analyses of the nutritional composition of S. latifolius by Yesufu and Hussaini [17] also reported that S. latifolius contains moderate water content. This proves that the powder from the leaves of the plant can be stored for a long time without being deteriorated. Table III gives the results of the chemical screening of $S$. latifolius leaf extracts.

TABLE III: RESULTS OF CHEMICAL SCREENING OF S. LATIFOLIUS LEAF
\begin{tabular}{cc} 
EXTRACTS \\
\hline Substances searched & Result \\
\hline Total Polyphenols & + \\
Flavonoids & + \\
Anthocyanes & - \\
Tanins & + \\
Leuco-anthocyanins & - \\
Alkaloïds & + \\
Saponins & - \\
Bound quinones & + \\
Steroids & + \\
Triterpenes & + \\
Free quinone & + \\
\hline
\end{tabular}

Legend: +: Compounds present, -: compounds absent.

From Table III, it can be seen that a total of eight secondary metabolites have been identified in the leaves of S. latifolius, including polyphenols, flavonoids, tannins, alkaloids, bound and free quinones, steroids and triterpenes. All three are absent, as are anthocyanins, leucoanthocyanins and saponins. These results corroborate those of Ikpefan et al. [18] who identified several compounds in the leaves of S. latifolius, such as alkaloids, flavonoids, tannins, terpenoids. Ngnokam et al. [19] isolated from the roots of the plant an indole alkaloid called nauclefolinin as well as five other known triterpenes. Shigemori et al. [20] discovered from the trunk bark of $S$. latifolius five indo-monoterpenic alkaloids named strictosamide and nauclefins A, B, C, D and E.

Fig. 2 shows the mineral content of $S$. latifolius leaves.

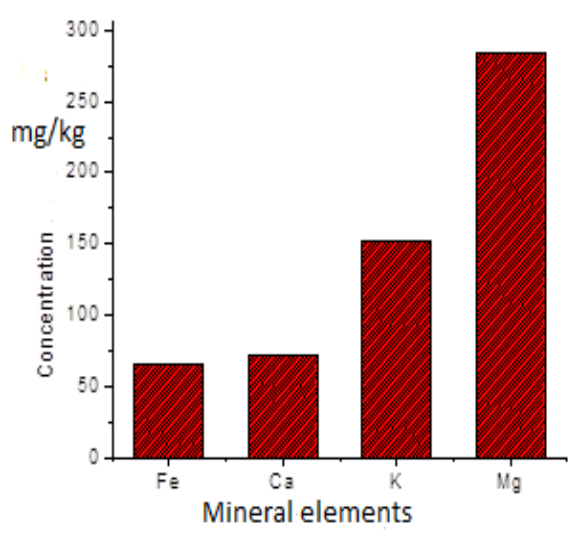

Fig. 2. Mineral elements content of S. latifolius leaves.

As can be seen in this figure, magnesium shows a remarkable predominance in the leaves of the plant compared to the other elements detected $(\mathrm{Fe}, \mathrm{K}, \mathrm{Ca})$. Nevertheless, potassium presents a non-negligible concentration in the leaves of $S$. latifolius. These results confirm Plassart research [16] which reveals that $S$. latifolius is a plant that contains more magnesium, calcium and potassium. 


\section{Evaluation of Biological Activities}

1) Evaluation of antibacterial activity

Table IV shows the results of the antibacterial activity of different extracts of $S$. latifolius.

TABLE IV: RESULTS OF THE ANTIBACTERIAL ACTIVITY OF DIFFERENT EXTRACTS OF S. LATIFOLIUS

\begin{tabular}{ccc}
\hline \multirow{2}{*}{ Extracts } & \multicolumn{2}{c}{ CMI $(\mu \mathrm{g} / \mathrm{mL})$} \\
\cline { 2 - 3 } & S. aureus ATCC 25923 & E. coli ATCC 8739 \\
\hline Ethanol & 1000 & 1000 \\
Ethyl acetate & 500 & 4000 \\
\hline Legend: ATCC: American Type Cell Collection, MIC minimum inhibitory \\
concentration.
\end{tabular}

From Table IV it appears that two bacterial strains used have a low sensitivity to $S$. latifolius leaf extracts (MIC greater than or equal to $500 \mu \mathrm{g} / \mathrm{mL}$ ) [21]. This resistance can be justified by the nature of the bacterial walls but also by the compounds contained in the $S$. latifolius leaves.

\section{2) Evaluation of antioxidant activity}

The results of the antioxidant activity assessment are shown in the table below:

TABLE V: PERCENTAGE OF DPPH INHIBITION AND FE ${ }^{3+}$ REDUCTION IN THE PRESENCE OF S. LATIFOLIUS LEAF EXTRACTS

\begin{tabular}{cccc}
\hline \multirow{2}{*}{$\begin{array}{c}\text { Concentration } \\
(\mu \mathrm{g} / \mathrm{mL})\end{array}$} & VIT C & DPPH & FRAP \\
\hline 10 & 85,7 & 68,06 & 48,5 \\
20 & 88,2 & 76,2 & 51,7 \\
30 & 88,7 & 86,3 & 51,9 \\
40 & 89,7 & 86,7 & 54,4 \\
50 & ND & ND & 62,1 \\
\hline
\end{tabular}

Legend : ND : not determined, VIT C : vitamin C.

From this table, it can be seen that the percentage of inhibition of the S. latifolius leaf extract is a function of the concentration. At $10 \mu \mathrm{g} / \mathrm{mL}$, we have a percentage inhibition of approximately $68 \%$ in the DPPH test and $48.5 \%$ in the FRAP test. These results show that the extract of our plant showed greater antioxidant activity than the vitamin $\mathrm{C}$ used as a positive control. These results are similar to the research of Plassart [16] who reported that the aqueous and ethanolic extracts of $S$. latifolius show a dose inhibition dependent on DPPH radical activity significantly comparable to the activity of ascorbic acid [16]. Since polyphenols are endowed with antioxidant properties [5], these results confirm our previously presented qualitative phytochemical analyses.

3) Evaluation of antihelmintic activity

Table VI gives the time of paralysis of earthworms in the presence of $S$. latifolius extracts.

TABLE VI: TIME OF PARALYSIS OF EARTHWORMS IN THE PRESENCE OF $S$.

\begin{tabular}{cccc}
\hline \multicolumn{4}{c}{ LATIFOLIUS EXTRACTS } \\
\cline { 2 - 4 } $\begin{array}{c}\text { Concentration } \\
(\mathrm{mg} / \mathrm{mL})\end{array}$ & \multicolumn{3}{c}{ Time of paralysis (minutes) } \\
\hline 10 & 7 & 7 & Ethyl acetate \\
5 & 13 & 12 & 6 \\
2,5 & 14 & 22 & 18 \\
1,25 & 23 & 36 & 28 \\
0,625 & 26 & 42 & 27 \\
& & & 34 \\
\hline
\end{tabular}

From this table, it can be seen that ethanol and ethyl acetate extracts significantly inhibited earthworm mobility. These results would be due to the presence of the compounds contained in the leaves of the studied plant. However, in the lowest concentration $(0.625 \mathrm{mg} / \mathrm{mL})$ of $S$. latifolius, we observed paralysis of the worms in less than 50 minutes after contact with the plant extracts. A predominance of ethyl acetate extract over ethanolic extract. This difference can be explained by the nature of the compounds that pass into ethyl acetate (less polar solvent). By comparing the extracts of the plant with the standard (Albentel) at low doses $(0.625$ $\mathrm{mg} / \mathrm{mL}$ ) we notice that there is not a significant difference. Table VII gives the mortality rate of earthworms in the presence of plant extracts.

TABLE VII: Mortality RATE of EARTHWORMS IN THE PRESENCE OF S. LATIFOLIUS EXTRACTS

\begin{tabular}{cccc}
\hline \multicolumn{4}{c}{ LATIFOLIUS EXTRACTS } \\
\cline { 2 - 4 } Concentration & \multicolumn{3}{c}{ Mortality rate $(\%)$} \\
\hline $\mathrm{mg} / \mathrm{mL})$ & Ethanol & Ethyl acetate & Albentel \\
\hline 10 & 100 & 100 & 100 \\
5 & 100 & 66,6 & 66,6 \\
2,5 & 88,9 & 55,5 & 66,6 \\
1,25 & 66,6 & 55,5 & 55,5 \\
0,625 & 55,5 & 33,3 & 33,3 \\
\hline
\end{tabular}

It appears from this table that the plant studied has antihelmintic activity. The ethanolic extract has a predominant activity ( $55.5 \%$ mortality rate) compared to the ethyl acetate extract $(33.3 \%)$. This shows that compounds with a strong deworming activity pass easily into the more polar solvent [22]. By comparing this plant with the positive control (Albentel), we notice that at low concentration $(0.625$ $\mathrm{mg} / \mathrm{mL}$ ) the acetate extract presents the same result as Albentel (33.3\% of the mortality rate) which is a modern product used in the treatment of gastrointestinal worms. These results are justified by the effect that this species contains secondary metabolites such as flavonoids, polyphenols, and tannins endowed with anti-helminthic properties. These results confirm the ethnobotanical data reported by Ademola et al. [23] which show the use of $S$. latifolius leaves by the Fulani tribe in Nigeria as regular dewormer against intestinal parasites such as Haemonchus contortus.

\section{CONCLUSION AND SUGGESTIONS}

In short, the objective of this study was to chemically and bioactively analyze the leaves of Sarcocephalus latifolius in order to contribute to the scientific valorization of the phytotherapeutic richness of the DR Congo. In this study, the antibacterial activity of $S$. latifolius leaves extracts was assessed using micro-dilution method and the antioxidant capacity of different plant extracts has been evaluated by determining their ability to reduce iron (III) to iron (II) and DPPH radical. The results obtained revealed that: The dry matter of the powder of the leaves of the plant is rich in fibers, crude proteins, lipids and carbohydrates. While its water content was revealed to be moderate (14.3\%); the leaves of $S$. latifolius are rich in trace elements, especially calcium $(\mathrm{Ca})$, magnesium $(\mathrm{Mg})$, potassium $(\mathrm{K})$, and iron $(\mathrm{Fe})$; the plant possesses the major groups of secondary metabolites such as total polyphenols, flavonoids, tannins, alkaloids, bound and free quinones, steroids and tri-terpenes, while it is poor in anthocyanins, leucoanthocyanins and saponins. The bacterial strains used were less sensitive to $S$. latifolius leaf extracts (MIC greater than or equal to $500 \mu \mathrm{g} / \mathrm{mL}$ ). The extracts of this plant showed significant anti-oxidant and antihelmintic activity, with a strong correlation between the DPPH and 
FRAP antioxidant potential assessment methods. Due to their interesting functional properties, this plant could be used in the formulation of a nutraceutical with strong antioxidant power to improve the antioxidant status of consumers, but also in the management of helminthiases.

\section{REFERENCES}

[1] D. Arome and E. chinedu. Evaluation of anti- proliferative activities of ethanolic extract of Sarcocephalus latifolius fruit and paullina pinnala leaf. Journal of pharmaceutical and Biosciences, (4):124-127, 2013.

[2] S. D. Dibong, M. E. Mpondo, A. Nigoye, M. F. Kwin, J. L. Betti. Ethnobotanique et phytomédecine des plantes médicinales de Douala, Cameroun. [Ethnobotany and phytomedicine of medicinal plants sold in Douala markets]. Journal of Applied Biosciences, 37: 2496 -2507, 2011.

[3] D. J. Newman, G. M. Cragg. Natural products as sources of new drugs over the 30years 1981. J.N Prod, 75: 311-335, 2012.

[4] K. N. Ngbolua, H. Rakotoarimanana, H. Rafatro, S. R. Urverg, V. Mudogo, P. T. Mpiana, D. S. T. Tshibangu. Comparative antimalarial and cytotoxic activities of two Vernonia species: $V$. amygdalina from the Democratic Republic of Congo and V. cinerea subsp vialis endemic to Madagascar. Int. Journal Biology Chemical Sciences. (1): 345-353, 2011.

[5] C. L. Inkoto, G. N. Bongo, P. M. Kapepula, C. A. Masengo, B. Z. Gbolo, C. Tshiama, N. K. Ngombe, J. B. Iteku, T. F. Mbemba, P. T. Mpiana, K. N. Ngbolua. Microscopic features and chromatographic fingerprints of selected congolese medicinal plants: Aframomum alboviolaceum (Ridley) K. Schum, Annona senegalensis Pers. and Mondia whitei (Hook.f.) Skeels. Emergent Life Sciences Research. 4(1): 1-10, 2018.

[6] K. N. Ngbolua, Shetonde OM., Inkoto CL., Masengo CA., Tshibangu DST., Gbolo BZ., Robijaona B., Fatiany PR and Mpiana PT. Ethnobotanical survey of plant species used in traditional medicine in kinshasa city (Democratic Republic of the congo). 3(2): 413-427, 2016

[7] M. M. Mongeke, K. T. N. Ngbolua, R. D. Bakola, C. L. Inkoto, P. N. Elikandani, C. Y. Mouli. Enquête sur les plantes utilisées en médecine traditionnelle par les Bambenga: pygmées du secteur de Dongo en République Démocratique du Congo. Revue Marocaine des sciences Agronomiques et Vétérinaires. 6 (4) : 469-475, 2018.

[8] F. N. Mulwele, K. N. Ngbolua, B. D-M. M. Yang and P.T. Mpiana PT. Ethno-botanical and ecological studies of plant species used in the treatment of sterility in Kenge city and its surroundings (Province of Kwango, Democratic Republic of the Congo). International Journal of Innovation and Scientific R. 26 (2):600-611.

[9] AOAC. Official méthods of analysis. Washington, DC. USA: Association of Official Analytical Chemists. $16^{\text {th }}$ ed, 4th revision. 1990.

[10] H. L. Nkasa, C. L. Inkoto, J-C. M. Muzomwe, E. I. Masengo, C. M. Muzomwe, C. M. Mulenga and K. M. Taba Kalulu. Phytochemical screening and antibacterial activity of phytomedecine mathesia, a drug use against buruli ulcer in Republic Democratic of the Congo (DRC). EJPMR, 7(2), 52-56, 2020.

[11] E. H. Hanane, F. Abdellah, Abdesslam E., Dalila B., Hassane G., Brahim EB., Mohammed L. (2013). Etude comparative de la composition minérale des constituants de trois catégories de Ceratonia siliqua L. (Comparative study of the mineral composition of the constituents of three varieties of Ceratonia siliqua L.) Journal. Mater. Environemental. Sciences, 4 (2):165-170, 2013.

[12] G. Bongo, C. Inkoto, C. Masengo, C. Tshiama, E. Lengbiye, R. Djolu, M. Kapepula, K. Ngombe, T. Mbemba, D. Tshilanda, P. Mpiana, K. N. Ngbolua. Antisickling, Antioxidant and Antibacterial Activities of Afromomum alboviolaceum (Ridley) K. Schum, Annona senegalensis Pers. and Mondia whitei (Hook. f.) Skeels. American Journal of Laboratory Medecine, 2(4): 52-59, 2017.

[13] G. K. Dash, P. Suresh, S. K. Sahu, D. M. Kar, S. Ganapaty and S. B. Panda. Evaluation of evolutus alsinoides linn. For Antihelminthic and antimicrobial activities. Journal of natural remedies (2):182-185, 2002.

[14] X. Li, Y. Xing, Y. Jiang, Y. Ding, W. Li. Antimicrobial activities of $\mathrm{ZnO}$ powder-coated PVC film to inactivate food pathogens." International Journal of Food Science \& Technology, 44(11):21612168, 2009.

[15] M. P. Kapepula, P. B. Ngumbi, K. M. Kawayidiko, D. A. Mpanzu, T. Franck, A. M. Mickalad, M. Frédérich, N. N. Kabamba and M. Tsobo. Anti-inflammatory and antioxydant activities of Pungia congoensis, a traditional vegetable consumed by yombe people from Kongo Central area (D.R.Congo). Journal of natural product Research, 2017.
[16] L. Plassart. Sarcocephalus latifolius (Sm) Bruce : Etude botanique, chimique et pharmacologique ; Thèse, Université de Rouen (UFR de médecine et de pharmacie). 2015.

[17] H. B. Yesufu and I. M. Hussaini. Studies on Dietary Mineral Composition of the fruit of Sarcocephalus latifolius (Smiith) Bruce (Rubiaceae). J Nutr Food Sci, 2014.

[18] E. Ikpefan, B. A. Ayinde, A.O. Adedokun. Comparative phytochemical, cytotoxic and growth inhibitory effects of the leaf and root barks of Sarcocephalus Latifolius (J.E. Smith) E.A. Bruce (Rubiaceae). (4): 162-169, 2014.

[19] Ngnokom, J. F. Ayafor, J. D. Connoly, J. M. Nuzillard. Nauclefolinine: A new alkaloid from the roots of Nauclea latifolia. BulletinChemical Society Ethiopic, (2):173-176, 2003.

[20] H. Shigemori, T. Kagata, H. Ishiyama, F. Morah, A. Ohsaki, Kobayashi. Naucleamides A-E, new monoterpene indole alkaloids from Nauclea latifolia. Chem. Pharm.Bull, 51(1):58-61, 2003.

[21] K. N. Ngbolua, G. N. Bongo, C. A. Masengo, R. D. Djolu, P. T. Mpiana, Mudogo V., Lassa K., Huruma NT. Ethno-botanical survey and Ecological study of Plants resources used in Folk medicine to treat symptoms of Tuberculosis in Kinshasa City, Democratic Republic of the Congo. Journal of Modern Drug Discovery and Drug Delivery Research. V1I3, 2014.

[22] W. W-M. Mbembo. Evaluation in vitro des activites anti-radicalaire et antihelmethique des feuilles de Artocarpus heterophyllus lam. (moraceae). Inédit, mémoire de licence, Unikin, Faculté des Sciences, Département de Biologie. p. 48, 2017.

[23] I. O. Ademola, B. O. Fagbemi, S. O. Idowu. Anthelmintic efficacy of Nauclea latifolia extract against gastrointestinal nematodes of sheep: In vitro and in vivo studies. African journal of traditional, complementary and alternative medicines 4(2):148-156, 2007.

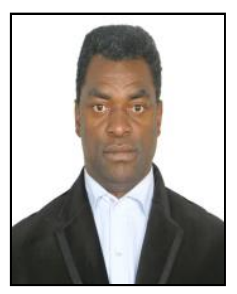

Prof. Jeff B. Iteku obtained/Bachelor of Science in Biology (Molecular biology), his from the University of Kinshasa, Democratic Republic of the Congo in 2000. He obtained his Master of Science and $\mathrm{PhD}$ in Biology (Biochemistry and Molecular Biology) at the Northeast Normal University, School of Life of Sciences, People's Republic of China in 2009 and 2014 respectively.

He currently works as Full professor in the department of Biology, Faculty of Sciences, University of Kinshasa, Democratic Republic of the Congo. His field of research is Immunology, Endocrinology, Bacteriology and Biochemistry. Prof J. B. ITEKU is member ACASTI.

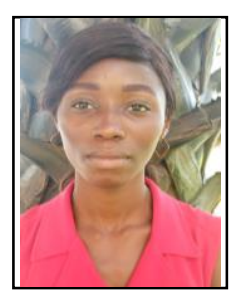

Mrs Ornella V. Makaya was born in Kinshasa, Democratic Republic of the Congo on the $06^{\text {th }}$ of April 1996. She obtained her Bachelor of Science in Biology (Molecular Biology), from the University of Kinshasa, Democratic Republic of the Congo in 2018.

She currently works as Junior Lecturer in the Department of Biology, Faculty of Science, University of Kinshasa, Democratic Republic of the Congo.

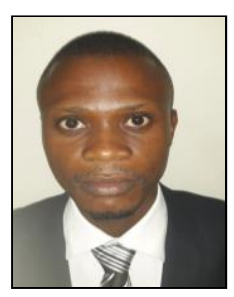

Mr Clément L. Inkoto was born in Bokungu on the $2^{\text {th }}$ June 1990, Democratic Republic of the Congo. He obtained his state diploma in Technical humanities, option Agriculture in 2009. He brilliantly carries out his studies in Biology which he completes in 2016 with the mention distinction in the last year of graduation and for the last year of Bachelor degree. Currently, he is a Master's student, specializing in Cell Biology at the Department of Biology, University of Kinshasa, Democratic Republic of the Congo. His Hindex is: 10 (ReasearchGate \& Google Scholar).

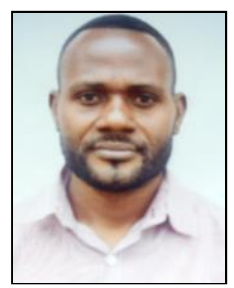

Mr Samy Ngunde-Te-Ngunde was born in Yakoma, North Ubangi Province, Democratic Republic of the Congo on the 02th July 1988. He obtained his Bachelor of Science in Biology (Molecular Biology), from the University of Kinshasa, Democratic Republic of the Congo in 2015. He is Master of Science student Biology, Molecular Biology at the Department of Biology, University of Kinshasa. He currently works as senior Lecturer at the Higher Pedagogical Institute Republic of the Congo. of Yakoma in North Ubangi Province, Democratic 


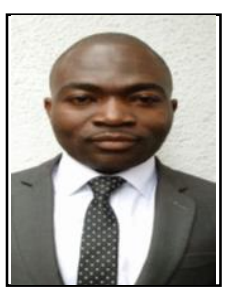

Mr Emmanuel M. Lengbiye was born in Yakoma, North Ubangi Province, DR. Congo on the $10^{\text {th }}$ of December 1987. He obtained Bachelor of Science in Biology (Molecular Biology), from the University of Kinshasa, Democratic Republic of the Congo in 2015. He has his Master of Science Biology in August 2021. $\mathrm{He}$ currently works as Junior Lecturer in the Department of Biology, Faculty of Science, and University of Kinshasa, Democratic Republic of the Congo.

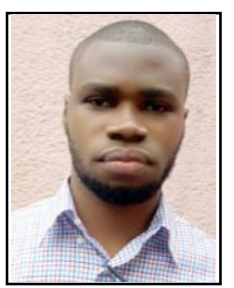

Mr. Joseph D. Tshidibi was born in Kinshasa, Democratic Republic of the Congo on the $11^{\text {th }}$ of May 1993. He obtained his Bachelor of Science Biology (Molecular Biology), from the University of Kinshasa, Democratic Republic of the Congo in 2015.

He currently works as Junior Lecturer in the Department of Biology, Faculty of Sciences, University of Kinshasa,

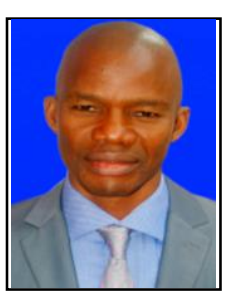

Prof. Koto-Te-Nyiwa Ngbolua obtained his Bachelor of Science Hons in Biology (Biotechnology), from the University of Kinshasa, DRC in 2002; Master of Science in Molecular Biology from the same University in 2005. He is Doctor of Philosophy in Molecular Biology from the University of Kinshasa and Malagasy Institute of Applied Research (IMRA, Madagascar) since 2012.

Dr Ngbolua is Full Professor of Molecular biology, Biochemistry, and Biophysics at the University of Kinshasa and he is Former Chancellor/Rector of the University of GdadoLite (Province of Nord-Ubangi) in DRC. He has his expertise in Biodiversity monitoring and Biological evaluation of medicinal plants (Bioguided fractionation assays) and structural characterization of bioactive secondary metabolites of relevance for improving human health and wellbeing. His $\mathrm{H}-$ index is: 34 (ReasearchGate); 32 (Google Scholar). 